\title{
УЛАНЧАВАњЕ НОМИНАЛИЗАЦИЈА У ШКОЛСКИМ УЏБЕНИЦИМА
}

\begin{abstract}
У овом раду биће посматран процес уланчавања номинализација у уџбеницима за основну школу, тачније посматрано је уланчавање девербативних и деадјективних именица у подврсти научног стила, у уџбеничком подстилу. Циљ истраживања је да се утврде синтаксичко-семантичке карактеристике овако употребљених девербативних и деадјективних именица и да се отвори питање њиховог потенцијалног утицаја на степен разумљивости и стилске особености самог текста. Анализа је показала да се у три уџбеника из физике за основну школу могу уочити вишеструке номинализације, најчешће двоструке, али да је знатно чешћи случај да ради скраћивања дужине реченице и постизања уопштености, анонимизације, неовремењености, статичности исказа, веома често долази до уланчавања номинализација.
\end{abstract}

Кључне речи: номинализације, девербативне именице, деадјективне именице, уланчавање номинализација, језик уџбеника, српски језик.

1. Увод. О процесу номинализације, његовим синтаксичким, семантичким и прагматичким аспектима у различитим функционалним стиловима ${ }^{1}$ савременог српског језика писано је доста. Намера нам је да се овом приликом усредсредимо првенствено на уланчавање номинализација будући да ова појава није довољно истражена, посебно не у језику уџбеника за основну школу. Циљ истраживања јесте утврђивање синтаксичко-семантичких карактеристика овако употребљених девербативних и деадјективних именица, али и отварање питања потенцијалног утицаја овог процеса на степен разумљивости и стилске особености самог текста. ${ }^{2}$ Анализом су обухваћена три уџ-

\footnotetext{
*natasakis14@gmail.com

${ }^{1} \mathrm{O}$ врстама функционалних стилова и њиховим карактеристикама видети детаљније у: Тошовић 1988.

${ }^{2}$ Једно илустративно истраживање везано за језик основношколских уџбеника урађено је са циљем да се прикажу подаци који се односе на субјективни доживљај ученика о томе колико користе уџбенике и у којој мери су им уџбеници појединих предмета тешки, односно лаки. Посебно важан део истраживања тиче се ставова ученика о томе који су аспекти језика уџбеника
} 
беника из физике, за шести, седми и осми разред основне школе. На самом почетку ваљало би указати на неке особености функционалног стила којем припадају школски уџбеници као дидактичка средства, а потом и на опште карактеристике језика уџбеника.

1.1. Текстови уџбеника за основну и средњу школу припадају научном и научнопопуларном ${ }^{3}$ стилу, при чему се од текстова који су по својој намени и дискурсним карактеристикама део научног стила у ужем смислу (стручне монографије, текстови објављени у стручним часописима и енциклопедијама) разликују по томе што имају углавном информативно-експликативан карактер, иако се и у уџбеницима из биологије, физике, хемије и математике често примењује и експериментално-индуктивна метода (Васић 1987: 145). На основу тога, али и других специфичности које се везују за језик уџбеника може се говорити о посебном уџбеничком подстилу.

За научни стил обично се као основне особине везују: апстрактност, јасност, тачност, објективност и логичност. Ове карактеристике постижу се првенствено: употребом лексема у основном, нефигуративном значењу, а у фигуративном само онда ако се такво значење контекстуално може разрешити; употребом лексема са апстрактним значењем, употребом прецизне и развијене терминологије; употребом сложених реченица, често са узрочно-последичним односом; употребом имперсоналних и пасивних реченица; честом номинализацијом; употребом потенцијала; употребом глаголских времена у основном темпоралном значењу; честом употребом модалних речи и израза у функцији реченичних модификатора (Васић 1987: 146). Вера Васић истиче да у језику уџбеника фреквентност и инвентар издвојених језичких средстава мора „бити у корелацији са ступњем језичке и когнитивне развијености ученика", односно да језик уџбеника мора бити прилагођен језику ученика (1987: 146). Степен прилагођености тиче се првенствено избора лексике и терминолошких решења, дужине и структуре реченице. Дијана Плут истиче да научни текст, у нашем случају текст уџбеника, не би требало да садржи компликован речник, превише нових речи по лекцији, превише апстрактних појмова. Реченице не би требало да буду предуге, а структура реченице прекомпликована (1993: 135). Аутори приручника Водич за добар уибеник као стандарде квалитета језика уџбеника наводе: поштовање језичке норме, објашњење значења непознатих речи и контролу дужине реченице (Ивић и др. 2012: 129). Сугестија је да „кад год је то могуће, боље је да се дуга реченица разложи на више краћих (ако се тиме не угрожава изражавање

одговорни за тешкоће које имају при разумевању текста (Шефер и др. 2008: 354). „Резултати показују да се уџбеници наративних - друштвених и природних - предмета (историја, географија, биологија) најчешће користе мада су често недовољно разумљиви због обимности, неприступачног речника и великог броја детаља, а уџбеници природних наука (хемија и физика) сувише су формализовани и имају превише нејасних објашњења због чега се ређе користе" (Шефер и др. 2008: 366). Када се ради о уџбеницима из физике, испитаници као разлоге због којих су им у целини тешки наводе: неразумљиве стране речи (43\%), нејасан текст (39\%), тешке дефиниције (35\%), нејасна објашњења (34\%) и опширност текста (32\%) (исто: 363-364).

${ }^{3}$ У раду $О$ језику науке (2008) Душка Кликовац даје преглед најважнијих карактеристика научног функционалног стила, а издвојене особине анализира у одломку из научног текста из области лингвистике. 
сложенијих мисли). С друге стране, постепено повећање дужине и сложености реченице, ако је добро одмерено, може бити само по себи један важан образовни циљ” (Ивић/Пешикан/Антић 2012: 130). Просечна дужина реченице у основношколским уџбеницима не би смела да буде већа од 10-12 речи (у зависности од структуре реченице), док се двадесетак речи у реченици наводи као максимална дужина (такође у зависности од структуре реченице) (Ивић и др. 2012: 130). У овом раду биће управо посматран однос дужине и структуре реченице који су умногоме одређени употребом номинализованих структура.

2. Према синтаксичким карактеристикама и улози у структурирању реченице, па и утицају на стилске особености читавог текста, направићемо појмовно-терминолошко разграничење 4 између неколико аспеката уланчавања номинализација. Може се у том смислу говорити о вишеструким номинализацијама, уланчавању и нагомилавању номинализација.

Вишеструке номинализације остварују се на нивоу синтагме. Под овим појмом подразумева се појава две или више од две номинализоване структуре у оквиру исте синтагме. У језику посматраних уџбеника појава двоструких номинализација уочава се у свим реченичним позицијама: $(7,26)^{5}$

Овај општи закључак о деловању два тела познат је као закон акције и реакције...

На Земљи две силе пружају отпор кретању тела. $(7,66)$

Одредите његову висину пењања. $(7,69)$

Свако тело у кретағу, у реалним - свакодневним условима, по престанку дејства „вучне” силе успорава... $(6,40)$

Сасвим очекивано, имајући у виду да се ради о уџбеницима намењеним основцима, троструке номинализације срећу се веома ретко, док комплексније структуре нису уочене.

Видимо да увек када делује сила на тело долази до промене брзине његовог креmања. $(7,11)$

Уланчавағе номинализованих конструкција, као општији појам, подразумева појаву више номинализација у једној реченици. Њиме су обухваћене вишеструке номинализације у једној синтагми, као и све номинализације у различитим реченичним функцијама у оквиру исте реченице. Појам уланчавања номинализација односи се и на синтаксичке конструкције ${ }^{6}$ у којима

\footnotetext{
${ }^{4}$ Детаљније о овом проблему видети у: Киш 2018.

${ }_{5}^{5}$ У загради иза сваког примера наводи се извор: први број показује да ли се ради о уџбенику из физике за шести, седми или осми разред, а други број јесте страница са које је пример преузет.

${ }^{6}$ Александар Белић прави разлику између простих (ору земљу) и сложених синтагми (ору плугом и ралицом), наводећи да су сложене синтагме многочлане синтагме које обједињује заједничка функција и нису ни у каквом међусобном односу (1998: 128). У Нормативној граматици српског језика (Пипер/Клајн 2013: 260) наводи се пак да речи у напоредном синтаксичком односу не чине синтагму него синтаксичку конструкцију у којој нема управног и зависног дела и повезане су саставним, раставним или супротним напоредним односом (Говори о брату и сестри).
} 
номинализације имају исту функцију, односно налазе се у напоредном односу у којем се не разликују управни и зависни део.

Овим повезивањем може да се мења укупна отпорност струјног кола, а тиме се утиче на јачину струје у колу. $(8,78)$

То је талас код кога се уочава згушњавање и разређивање јер честице еластичне средине осцилују у правцу простирањ $а$ таласа. $(8,14)$

Зато је за руковаъе радиоактивним изворима потребна посебна обука, заштита и радна дисциплина. $(8,113)$

Термин нагомилавање користићемо првенствено за вредновање употребе номинализованих структура као прекомерне или стилски лоше обликоване. Нагомилавање номинализација схваћено у овом смислу у домену је општег процеса бирократизације језика ${ }^{7}$. У примерима који следе видимо нагомилавање девербативних именица које је често праћено и нагомилавањем генитива, што умногоме отежава разумевање самог садржаја реченице, односно текста.

ПрИнциП рада ОВИХ МЕРНИХ ИНСТРУМЕНАТА се заснива На претварању ЕЛЕКТРИЧНЕ У меХаничку енергију померањ $а$ КАЗАљКЕ На сату. $(8,73)$

У оПштем случају примена КИФЕРОВИХ ПРАВИЛА доводИ до ПРОБЛЕМА решењ $а$ СИСТЕМА ЈЕДНАчИНА Што је нетривијалан математички проблем, па ћемо се ми задовољити једноставнијом применом која се односи на везивање отпорникА. $(8,78)$

3. Синтаксичко-семантички односи који се остварују унутар вишеструких номинализација у највећем броју случајева подразумевају однос допуњавања или комплементације. Као што је речено, у нашем корпусу издвојено је највише двоструких номинализација у којима се у позицији управног члана налази девербативна или деадјективна именица. У позицији зависног члана синтагме такође се могу наћи и девербативне и деадјективне именице, по правилу у облику слободног генитива или акузатива са предлозима за и на са објекатским или експликативним значењем. ${ }^{8}$

- Зависни члан синтагме у функцији допуне објекатског типа уз девербативну именицу, односно кондензатора допунске објекатске клаузе:

$\mathrm{N}_{\text {Dev }}+$ Compl $\left[\mathrm{N}_{\text {Dev (Gen) }}\right]^{9}$

При оПИСИвАњУ ТоГ КРЕТАњА Најзгодније нам је да време кретањ $а$ меримо од тог почетног тренутка... $(6,18)$

АКО ТеЛО ПОСЛО ПРЕСТАНКА ДЕЛОВАЊА ${ }^{10}$ СИЛЕ ПОВРАТИ ПРВОБИТАН ОБЛИК, ОНДА СЕ ТАКВА ДЕФОРМАЦИЈА НАЗИВА ЕЛАСТИЧНА ДЕФОРМАЦИЈА. $(6,33)$

\footnotetext{
${ }^{7}$ Преглед особина бирократског језика дала је Душка Кликовац у тексту О бирократизацији српског језика (2001).

${ }^{8}$ Семантичке и синтаксичке карактеристике падежа анализиране су према типологији Иване Антонић (Пипер и др., 2005: 119-300).

${ }^{9}$ Скраћенице и симболи: $\mathrm{N}$ - именица, $\mathrm{N}_{\text {Dev }}$ - девербативна именица, $\mathrm{N}_{\text {Deadj }}$ - деадјективна именица, Compl - допуна / комплемент, Det - детерминатор, неконгруентни атрибут, Nom - номинатив, Dat -датив, Ак - акузатив, Instr - инструментал, Lок - локатив, + - повезује се, [ ] синтаксичка јединица која обавља одређену синтаксичко-семантичку функцију.

${ }^{10}$ Девербативна именица у генитиву у функцији допуне друге девербативне именице изведене од семикопулативног фазног глагола може се одредити као допуна којом се именује пропозициони објекат (Пипер и др. 2005: 197).
} 
$\mathrm{N}_{\mathrm{Dev}}+\operatorname{Compl}\left[\mathrm{N}_{\mathrm{Dev}(\mathrm{NA}+\mathrm{Ak})}\right]^{11}$

Електроника је област технике у којој се примењује директно дЕЛовАњЕ НА ПОНАшАњЕ електрона у одређеним материјалима. $(8,120)$

$\mathrm{N}_{\text {Dev }}+$ Compl [ $\left.\mathrm{N}_{\text {Deadj (Gen) }}\right]$

МЕРЕњЕ дужинЕ неког тела јесте одређивање растојања од једног до другог краја тела. $(6,44)$

- Зависни члан синтагме у функцији семантичке допуне експликативног ${ }^{12}$ типа уз девербативне и деадјективне именице као кондензатор допунске клаузе:

$\mathrm{N}_{\text {Dev }}+$ Compl $\left[\mathrm{N}_{\text {Deadj (ZA+Ak) }}\right]$

Нажалост, БорБА ЗА УВођЕњЕ наизменичне струје била је далеко од „фер-плеја” и Тесла је стално трпео ниске ударие уз истовремено указивање почасти за своја достигнyћa. $(8,97)$

$\mathrm{N}_{\text {Deadj }}+$ Compl [ $\left.\mathrm{N}_{\text {Dev (Gen) }}\right]$

Пажљива и образложена поређењ $а$ дају нам могућност добре пРоценЕ неке величине и без њеног мерења. $(6,8)$

Анализа корпуса показала је да до уланчавања номинализација у оквиру исте синтагме долази и када је један од зависних чланова права именица, при чему сваки од делова синтагме својом лексичком семантиком захтева експликацију, односно допуњавање и конкретизацију значења.

Без обзира где се предмет налази у односу на огледало, пРименА закона одьијАњА показује да се одбијени паралелни зраци расипају као да су дошли из жиже на другој страни испупченог огледала. $(8,33)$

ОБЈАВљИВАњЕ резултата ПОСМАТРАњА небеских тела довело је до првог Галилејевог озбиљнијег сукоба са свештеницима, који ће касније кулминирати његовим појављивањем пред инквизицијом. $(8,42)$

Уочена је и једна специфичност условљена тематиком и чињеницом да се ради о текстовима који припадају научном стилу. Наиме, приликом дефинисања и одређивања процеса или стања означених девербативним и деадјективним именицама, ради посебног истицања класе појава којима припадају, врши се категоризација појмова на вишем нивоу (Кликовац 2008). Често су на тај начин употребљене именице: процес, појава, стање, време, сила, вредност и сл.

Процес ПРЕНОШЕњА осциЛаторног КРЕТАњА (осцилација) од једНе на друге честице дате средине, назива се таласно кретање, или кратко таласи. $(8,13)$

Овде се дешава појава НАЕЛЕКТРИСАњА ДОДИРОМ. $(8,49)$

Још је Њутн уочио да се тела опиру ПРОмЕНИ стања кРЕТАњА. $(6,60)$

\footnotetext{
${ }^{11}$ Зависни члан синтагме може имати неко од нетипичних објекатских значења. У наведеном примеру друга девербативна именица употребљена је у значењу објекта утицаја уз девербативну именицу изведену од глагола са семантичким обележјем каузативности (Пипер и др. 2005: 203).

${ }^{12}$ Семантичке допуне уз глаголе и именице, којима се врши конкретизација и употпуњавање значења управне речи, одредили смо према семантичкој функцији као експликативне (Пипер и др. 2005: 135-136, 209-211).
} 
ОН ЗаВИСИ ОД брЗИНе И вреМена ТРАЈАњА КРЕТАњА... $(18,7)$

ОДРЕЪИВАњЕМ вредности ТЕЖИНЕ ИстИсНуТе ТечНости Истовремено се одређује и иНтензитет силе потискА. $(6,57)$

Однос детерминације унутар вишеструких номинализација знатно се ређе успоставља. По правилу се ради се о синтагмама у којима зависни члан синтагме има функцију атрибута исказаног субјекатским генитивом уз деадјективну именицу.

ЗНАЧАЈ њеГовог РАДА је схваћен тек касније... $(7,92)$

Показаћемо како се графички приказује зАвисност БРзинЕ и пута од времена при равномерном праволинијском кретању. $(7,21)$

Када је реч о уланчавању номинализација у више различитих реченичних функција, основно питање је које су позиције у том смислу најфреквентније. Како нам обим рада не дозвољава детаљнији опис овог проблема, овом приликом указаћемо само на једну општу тенденцију уочену у посматраним уџбеницима из физике. Наиме, у великом броју случајева, номинализације се налазе у позицији граматичког субјекта реченице, док остале номинализације могу бити делови предиката или пак различити типови допуна и детерминатора. Уланчавање номинализације у овом случају може се сматрати пожељним будући да би ученици могли имати потешкоће управо у реконструисању субјекатске клаузе. ${ }^{13}$

Нагло и неконтролисано ослоБАЂАњЕ оволике енергије у делићу секунде доводи до експлозије огромних размера. $(8,112)[\leftarrow$ То када се оволика енергија нагло и неконтролисано ослобађа у делићу секунде доводи до експлозије ...]

ПронАЛАЗАК ланчане фузионе реакције омогућио је ослобађање огромних енергија у виду топлоте. $(8,112)[\leftarrow$ То што је пронађена ланчана фузиона реакција омогућило је ослобађање ...]

У резонаторима се поЈАчАњЕ звука постиже изазивањем механичке резонанције. (8, 18) $[\leftarrow$ То да се појача звук у резонаторима постиже се ...]

4. Пажњу, надаље, усмеравамо на улогу уланчавања номинализација у обликовању језичког израза у уџбеницима из физике. Економичност, као једна од основних карактеристика процеса номинализације, у том погледу има важну улогу, те се може рећи да се уланчавањем девербативних и деадјективних именица постиже одговарајућа дужина реченице без значајнијег утицаја на разумљивост реченице. Ово се посебно односи на ситуације у којима су различитим детерминаторима (присвојни придеви и присвојне заменице, субјекатски генитив) исказани подаци о вршиоцу радње или носиоцу именоване особине, као и о објекту кондензованих реченичних предикација (објекатски генитив).

Квалитет микРоскоПА цени се према њЕговом увећању. $(8,41)$

Овим повезивањем може да се мења укупна отпорност струјног колА, а тиме се утиче на јачину струје у колу. $(8,78)$

\footnotetext{
${ }^{13} \mathrm{O}$ допунским субјекатским клаузама класификованим према синтаксичко-семантичким особинама управне предикације видети у Синтакси сложене реченице у савременом српском језику (Пипер и др. 2018).
} 

$(8,18)$

У резонаторима се појачање ЗВУКА Постиже изазивањем МЕХАНИЧКЕ РЕЗОНАНЦИЈЕ.

Ипак, стандарди дужине реченице и њене структуре могу доћи у колизију, посебно ако се има на уму да се повећавањем броја номинализација у једној реченици утиче на повећање броја информација, односно број кондензованих реченичних структура.

Једна од необичних особина материјала је тзв. суперпроводљивост, а то је провођење електричне струје кроз проводник, без губитака на загревање. $(8,121)$

Једна од необичних особина материјала је [ $\leftarrow 1$. то да су суперпроводљиви], а то је

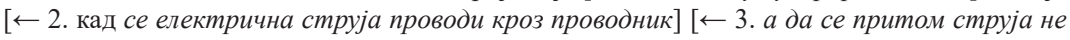
губи] [њ 4. када се материјали загревају]

Питање које се може поставити, када је реч о примерима овог типа, јесте колико је уланчавање номинализација у складу са језичким и когнитивним развојем ученика и да ли ће приликом читања текста без посебног напора моћи правилно да реконструишу дубинске садржаје. Није ли реченица са експлицираним реченичним структурама примеренија језику ученика од оне са четворочланом синтагмом, односно троструком номинализацијом као у примеру који следи?

За утврђивање законитости кретања клатна довољно је припремити клатна са гвозденим и дрвеним куглицама, по могућству исте величине. $(8,11)$

[Да би се утврдило како се клатно креће, довољно је припремити клатна са гвозденим и дрвеним куглицама]

5. Разумљивост и јасноћа исказа посебно су важни када се у уџбеницима дефинише неки појам. У дефиницијама, које теже постизању високог степена општости, објективности, анонимизације и неовремењености, сасвим је очекивана појава уланчавања номинализација. Наш корпус показује да је концентрација девербативних и деадјективних именица већа у дефиницијама него у осталим елементима уџбеничког текста.

Број осиялација у једној секунди је учесталост или фреквенција. $(8,10)$

Трансверзални талас је талас код којег настаје поремећај еластичне средине у облику брегова и доља, јер честице осцилују нормално на правац простирања таласа. $(8,14)$

Преношење наелектрисања ${ }^{14}$ са једног тела на друго или премештање наелектрисања у електричном пољу уопште, представља струјање наелектрисаних честица, односно, електричну струју. $(8,66$, д)

Не сме се, међутим, изгубити из вида да се структура реченице у којој долази до уланчавања већег броја номинализација значајно удаљава од начина изражавања својственог деци тог узраста, те постоји могућност да ученици усвајају дефиниције без аналитичког посматрања садржаја исказа.

${ }^{14}$ Девербативне и деадјективне именице које у овом дискурсу, односно у физици као једној од фундаменталних наука, имају статус термина нису укључене у спроведену анализу будући да немају функцију кондензатора реченичног садржаја. Именице овог типа су: наелектрисање, величина, снага, притисак и сл. 
6. Још једна синтаксичка структура карактеристична, између осталог, за научни стил, јесте декомпоновани предикат. ${ }^{15}$ Бројни су разлози, језички и нејезички, који утичу на појаву овог типа аналитичког предиката. ${ }^{16}$ Примери који следе показују да уланчавањем номинализација структура реченице постаје комплекснија при чему се дужина реченице декомпоновањем предиката заправо повећава.

Радиоактивно зрачење при проласку кроз супстанцију вРши јонизащију атома. $(8,113)$

Ако тако размишљамо, видећемо да је постојање разлике потенцијала између две тачке, неопходан услов да дођЕ до кретања наелектрисања између њих. $(8,56)$

Видимо да увек када делује сила на тело долАзи до промене брзине његовог креmања. $(7,11)$

Трансверзални талас је талас код којег нАСТАJЕ nоремећај еластичне средине у облику брегова и доља, јер честице осцилују нормално на правац простирања таласа. $(8,14)$

Употребу декомпонованих предиката у овим и сличним примерима можемо приписати ванјезичким моментима, пре свега уопштености и апстрактности тематике (Радовановић 1990), односно чињеници да се ради о текстовима који припадају подтипу научног стила. Може се чак говорити и о одређеним предикатским структурама карактеристичним управо за физику као научну дисциплину. Такви су, на пример, предикати типа (из)вршити рад и (из)вршити кретање, који би, употребљени у неком другом стилу, могу звучати неприродно.

Значи да се под дејством електричних сила вРши РАд. $(8,55)$

Када се периодично кРЕТАњЕ ВРши увек при истој путањи са проласком кроз једну равнотежну тачку у различитим смеровима, онда је то осцилаторно кретање. $(8,9)$

Уланчавање номинализација и декомпоновање предиката ипак морају бити прилагођени језику ученика. У језику уџбеника посебно се мора водити рачуна о томе да се не употребљавају лоше обликоване предикатске конструкције или пак вишеструко декомпоноване конструкције (оперисати $\rightarrow$ извести операщију $\rightarrow$ извести оперативни захват).

Теслиним струјама успостављен је терапијски метод - дарсонвализација, за лечење нервних обољења, а оне се употребљавају и у електрохирургији зА ИзВОЂЕњЕ ДЕЛИКАТНИХ оПЕРАТИВНИХ ЗАХвАТА због уског реза и брзог згрушавањ $а$ крви. $(8,98)$

Различити материјали (метали) пРужАлу различиту отпоРНост протицағыу електричне струје. $(8,75)^{17}$

Иако њима меримо исту величину, резултат мерења не мора да буде исти јер ови инструМенти НЕМАЈУ исту ТАЧНОСТ. $(6,50)^{18}$

Видећеш како се вода опире кретању, због чега долАзи до узБуркАвАњА воде. $(6,59)^{19}$

\footnotetext{
${ }^{15} \mathrm{O}$ процесу декомпоновања предиката видети детаљније у: Радовановић 1990; Ивић 1995; Танасић 1995; Пипер 1999.

${ }^{16}$ Овом приликом посматрани су само они случајеви у којима се уз овај процес могу уочити и друге номинализоване структуре у истој реченици.

${ }^{17}$ Ово је пример замене девербативне именице деадјективном, иако се не ради ни о каквој особини, већ о активности, па би декомпоновани предикат требало да гласи пружати отпор.

${ }^{18}$ Било би једноставније рећи да мерни инструменти нису подједнако тачни.

${ }^{19}$ Говорећи о карактеристикама бирократског језика Душка Кликовац издваја употребу глагола доћи / долазити у предикатима овог типа наводећи да је често била критикована и од стране
} 
Уочене су и друге ситуације у којима, ради постизања општости и номиналности стила, долази до нагомилавања или обликовања номинализација које нису својствене језику основаца, чак и до погрешне употребе предлошко-падежних конструкција.

...а да би се тело кретало без успоравањ $а$, потребно је уложИТИ РАД ПРОТИВ ДЕЈСТВА ових силА! $(6,66)$

У сПОзНАли природе и њених основних законитости у 6. разреду учили смо и о узајамном деловању тела. $(6,40)$

Од тренутка избацивања камена из дечакове руке па до стизАњА камена на највиши ниво протекне време пењања. $(8,38)$

Механички рад представља савлађивање свих супРостАвљАњА на неком путу. $(7,64)$

У медицини се ултразвук примењује, на пример, пРИ откРивАњу разних неправилности (отеклина, рана, напрснућа и сл.) у телесним органима или нпр. за праћене развоја детета пре рођења. $(8,16)^{20}$

7. На самом крају, из овог кратког прегледа неких од аспеката процеса уланчавања номинализација, може се закључити да номинализације јесу важан елеменат научног дискурса, па и уџбеничког подстила. Употреба девербативних и деадјективних именица којима се кондензује реченични садржај и уланчавање већег броја ових језичких средстава у језику основношколских уџбеника има своје језичке и изванјезичке разлоге. Већим бројем номинализација значајно се смањује дужина реченице, постиже се уопштеност, објективност и неовремењеност, што је посебно значајно када је реч о дефиницијама. Видели смо, међутим, да уланчавање номинализација, нагомилавање генитива које прати процес номинализације, па чак и поједини случајеви декомпоновања предиката могу имати утицаја на степен разумљивости текста. Анализа показује да у највећем броју случајева аутори успостављају добру равнотежу између стандарда везаних за дужину и структуру реченице, као и за основне карактеристике језика науке, али да свакако има простора да се језик основношколских уџбеника из физике учини примеренијим језику ученика.

\section{ИЗВОРИ}

Вербић/Николић 2009: С. Вербић, Б. Николић, Физика за шести разред основне школе, Београд: Креативни центар.

Капор/Шетрајчић 2009: Д. Капор, Ј. Шетрајчић, Физика за седми разред основне школе, Београд: Завод за уџбенике.

Капор/Шетрајчић 2015: Д. Капор, Ј. Шетрајчић, Физика за осми разред основне школе, Београд: Завод за уџбенике.

стручњака, али и од стране лаика са добрим језичким укусом (2008: 53). Синтетички предикат у овом примеру био би и економичнији и природнији.

${ }^{20}$ У медицини се ултразвук не примењује док се откривају или када се откривају различити здравствени проблеми, већ зА њихово откривање, односно да би се они открили. 


\section{ЛИТЕРАТУРА}

Белић 1998: А. Белић, Општа лингвистика. О језичкој природи и језичком развитку, Књига I и II, Изабрана дела Александра Белића, 1. књига, Београд - Нови Сад: Завод за уџбенике и наставна средства - Будућност.

Васић 1987: В. Васић, О језику уџбеника, Гласник Одјељења умјетности, књ. 7, Титоград: Црногорска академија наука и умјетности, 145-158.

Ивић 1995: M. Ivić, O zelenom konju. Novi lingvistički ogledi, Beograd: Biblioteka XX vek.

Ивић/Пешикан/Антић 2012: И. Ивић, А. Пешикан, С. Антић, Водич за добар уибеник. Општи сандарди квалитета уибеника, Београд: Klett.

Киш 2018: Н. Киш, О уланчавању номинализованих структура, у: Српски језик: статус, систем, употреба. Зборник у част проф. Милошу Ковачевићу, Крагујевац: Филолошко-уметнички факултет, 361-376.

Кликовац 2001: Д. Кликовац, О бирократизацији српског језика, Наш језик, 34/1-2, 85-110.

Кликовац 2008: Д. Кликовац, Језик и моћ, Београд: Библиотека ХХ век.

Пипер 1999: П. Пипер, Аналитички глаголски изрази и декомпоновани предикати типа „изразити захвалност”, Зборник Матище српске за филологију и лингвистику, XLII, 37-44.

Пипер и др. 2005: П. Пипер и др., Синтакса савременога српског језика. Проста реченицุа, Београд: Институт за српски језик САНУ - Београдска књига - Матица српска.

Пипер/Клајн 2013: П. Пипер, И. Клајн, Нормативна граматика српског језика, Нови Сад: Матица српска.

Пипер 2018: П. Пипер и др., Синтакса сложене речениче у савременом српском језику, Нови Сад - Београд: Матица српска - Институт за српски језик САНУ.

Плут 1993: Д. Плут, Ваљаност уџбеничких текстова, Београд: Настава $u$ васпитање. Часопис за теорију и праксу, год. XLII, бр. 3-4, 264-265.

Радовановић 1990: M. Radovanović, Spisi iz sintakse i semantike, Sremski Karlovci - Novi Sad: Izdavačka knjižarnica Zorana Stojanovića - Dobra vest.

Танасић 1995: С. Танасић, Декомпоновање глагола и структура просте реченице, Јужнословенски филолог, LI, 157-166.

Тошовић 1988: В. Tošović, Funkcionalni stilovi, Sarajevo: Svjetlost.

Шефер и др. 2008: Ј. Шефер и др., Језик уџбеника: подстицај или препрека, Београд, Зборник Института за педагошка истраживања, год. 40, бр. 2, 347-368. 


\section{Nataša Kiš}

\section{THE CHAINING OF NOMINALIZATION STRUCTURES IN TEXTBOOKS}

\section{Summary}

This paper studies the multiple nominalizations in one subtype of scientific functional style. The chaining of nominalization structures are analysed in three physics textbooks for primary school. The aim of this paper is to show some of the syntactic and semantic characteristics of multiple nominalizations as well as to point to their possible influence on comprehensibility of text. The conducted research shows that chaining of deverbative and deadjectival nouns affects the reduction of the length of the sentence and also the objecivity, generalization, anonymity of the statement, which is recommended features in the language of the textbook.

Key words: nominalization, deadjectival nouns, deverbative nouns, chaining of nominalizations, syntax, semantics, language of textbook, Serbian. 